\title{
Distribution of the clpX gene in Brachyspira species and reactivity of recombinant Brachyspira pilosicoli ClpX with sera from mice and humans
}

Correspondence

David J. Hampson

d.hampson@murdoch.edu.au

Received 13 October 2006

Accepted 16 March 2007

\author{
Abdolreza Movahedi and David J. Hampson
}

\author{
Division of Health Sciences, School of Veterinary and Biomedical Sciences, Murdoch University, \\ Murdoch, WA 6150, Australia
}

\begin{abstract}
Previously, a clpX gene encoding a predicted $67 \mathrm{kDa}$ membrane-associated ATPase subunit of the Clp protease (ClpX) was identified in a porcine strain (95/1000) of the intestinal spirochaete Brachyspira pilosicoli. In the current study, the distribution of this large $c / p X$ gene was investigated in a collection of strains representing all seven Brachyspira spp. Using PCR with internal primers, an 878 bp portion of the gene was detected in 29 of 35 strains (83\%) of B. pilosicoli, 6 of 24 strains (25\%) of Brachyspira hyodysenteriae, 14 of 16 strains (88\%) of Brachyspira intermedia, 6 of 17 strains (35\%) of Brachyspira innocens, 1 of 6 strains (17\%) of Brachyspira murdochii, 1 of 2 strains (50\%) of Brachyspira aalborgi and not in the single strain of Brachyspira alvinipulli. The whole gene was sequenced from 20 Brachyspira spp. strains and compared with the clpX gene from B. pilosicoli 95/1000 (GenBank accession no. AY466377). The genes had $99.3-99.7 \%$ nucleotide sequence similarity and the predicted products had 99.7-100\% amino acid sequence similarity. The $c / p X$ gene from WesB, a human strain of $B$. pilosicoli, was cloned and expressed as a histidine-tagged fusion protein in Escherichia coli BL21. The purified protein was used to vaccinate mice and their sera were found to recognize the expected $\sim 67 \mathrm{kDa}$ protein in whole-cell preparations of WesB. Sera from mice vaccinated with formalin-treated whole-cell proteins of WesB reacted with the recombinant protein. These results indicate that $\mathrm{ClpX}$ is both conserved and immunogenic and hence might be useful as a subunit vaccine component for Brachyspira spp. infections. Sera from humans with no known exposure to $B$. pilosicoli reacted with the recombinant $\mathrm{ClpX}$ protein, indicating that it is unlikely to be useful as a reagent for serological detection of Brachyspira spp. infections.
\end{abstract}

\section{INTRODUCTION}

The genus Brachyspira includes seven species of anaerobic intestinal spirochaetes, several of which are pathogenic in humans and/or in various species of animals and birds (Hampson \& Stanton, 1997). The most common and important pathogenic species are Brachyspira hyodysenteriae, the agent of swine dysentery (Hampson et al., 2006a), and Brachyspira pilosicoli, the agent of intestinal spirochaetosis - a disease of many species including humans, poultry, pigs, dogs and horses (Hampson \& Duhamel, 2006).

Intestinal spirochaetosis is characterized by the end-on attachment of large numbers of spirochaetal cells to the luminal surface of the large intestine epithelium, to form a 'false brush border' (Harland \& Lee, 1967; Mikosza \& Hampson, 2001). The basis of the observed attachment is unknown, but it has been suggested that spirochaetal outer-membrane proteins may have an important role in this interaction (Trott et al., 2001). To date, relatively few outer-membrane proteins of Brachyspira pilosicoli or other
Brachyspira species have been characterized. Recently, Trott et al. (2003) identified a membrane-bound $61 \mathrm{kDa}$ clip protease (ClpX) homologue in porcine Brachyspira pilosicoli strain $95 / 1000$ by screening a Brachyspira pilosicoli genome library using a monoclonal antibody generated against a Brachyspira pilosicoli membrane vesicle preparation. They described the ClpX protein as an innermembrane protein of Brachyspira pilosicoli but with a low-density presentation in the outer membrane that accounted for the reactivity of the protein with the monoclonal antibody. ClpX ATPase is a member of a group of molecular chaperones involved in the conformational integrity of proteins under conditions of normal growth as well as under stress (Gottesman et al., 1993; Skinner \& Trempy, 2001).

In the current study, the distribution of the clpX gene amongst a large collection of Brachyspira spp. strains was determined by PCR analysis and the whole gene was sequenced in 20 strains of Brachyspira species. The clpX gene was expressed in Escherichia coli and the purified recombinant protein was used to immunize mice and to 
evaluate its reactivity with sera from mice and humans. The long-term aim of the study was to investigate recombinant $\mathrm{ClpX}$ as a potential subunit vaccine component for $\mathrm{Bra}$ chyspira infections and/or as a reagent for Brachyspiraspecific serological assays.

\section{METHODS}

Ethics. This work was conducted with the approval of the Murdoch University Animal and Human Ethics Committees.

Spirochaetal reference strains and culture conditions. A total of 101 Brachyspira species strains were used, comprising 35 strains of Brachyspira pilosicoli (from humans, pigs, dogs and chickens), 24 strains of Brachyspira hyodysenteriae, 17 strains of Brachyspira innocens, 16 strains of Brachyspira intermedia, six strains of Brachyspira murdochii, two strains of Brachyspira aalborgi and one strain of Brachyspira alvinipulli. The strains were obtained as frozen stocks from the culture collection held at the Reference Centre for Intestinal Spirochaetes, Murdoch University, Australia. The cells were thawed and plated onto trypticase soy agar (BBL) containing $5 \%$ $(\mathrm{v} / \mathrm{v})$ defibrinated ovine blood. The plates were incubated for $7-$ 10 days at $37{ }^{\circ} \mathrm{C}$ in anaerobic conditions generated using anaerobic Gaspak Plus sachets (BBL). The purity of each culture was examined by phase-contrast microscopy and pure cells were propagated in $10 \mathrm{ml}$ and then $100 \mathrm{ml}$ Kunkle's pre-reduced anaerobic broth, containing $2 \%(\mathrm{v} / \mathrm{v})$ fetal bovine serum and $1 \%(\mathrm{v} / \mathrm{v})$ ethanolic cholesterol solution (Kunkle et al., 1986).

Preparation of genomic DNA from Brachyspira spp. strains. Approximately $2 \times 10^{9}$ cells from mid-exponential phase spirochaetal growth were used to prepare chromosomal DNA using a DNeasy tissue kit according to the manufacturer's instructions (Qiagen). RNA was removed by adding $20 \mu \mathrm{l}$ RNase A ( $100 \mathrm{mg} \mathrm{ml}^{-1}$ ) to each sample, followed by incubation at room temperature for $2 \mathrm{~min}$. DNA concentrations were calculated by measuring the $A_{260}$ of the solution in a Lambda $25 \mathrm{UV} / \mathrm{Vis}$ spectrometer using UV WINLAB software (PerkinElmer).

Primer design and specification. Five sets of primers (one set for gene distribution analysis, three sets for sequencing and one set for cloning) were designed to be complementary to the internal and external regions of the $c l p X$ gene (Table 1). The oligonucleotides were designed using PRIMER DESIGNER software (Education and Scientific Software), SEQED version 1.0.3 (Applied Biosystems) and the AMPLIFY program version 1.2 (University of Wisconsin). Primers were purchased from GeneWorks.
PCR. The PCR amplification mixtures consisted of $1 \times$ PCR buffer, $1.5 \mathrm{mM} \mathrm{MgCl} 2$, $0.6 \mathrm{U}$ Taq DNA polymerase, $0.06 \mathrm{U} P f u$ DNA polymerase, $0.25 \mathrm{mM}$ each dNTP (Promega), $0.5 \mu \mathrm{M}$ of the primer set and 50-100 ng chromosomal DNA template (genomic DNA) in a total volume of 25 or $50 \mu$ l. Reactions were loaded into $0.2 \mathrm{ml}$ thinwalled thermocycling tubes (Multiply-Pro) and Ultrapure water (Fisher Biotech) was used to make up the reaction volume.

Thermocycling conditions consisted of an initial template denaturation for $5 \mathrm{~min}$ at $94{ }^{\circ} \mathrm{C}$, followed by 30-35 cycles of denaturation at $94{ }^{\circ} \mathrm{C}$ for $30 \mathrm{~s}$, annealing at $57{ }^{\circ} \mathrm{C}$ for $30 \mathrm{~s}$ and primer extension at $72{ }^{\circ} \mathrm{C}$ for $1-1.5 \mathrm{~min}$. The final cycle had the extension time increased to $7 \mathrm{~min}$ to complete synthesis of all strands. Amplified products were separated by electrophoresis in $1.2 \%(\mathrm{w} / \mathrm{v})$ agarose in $1 \times$ TAE buffer [40 mM Tris/acetate ( $\mathrm{pH} 8.0$ ), $1 \mathrm{mM}$ EDTA], stained by immersion in a $1 \mu \mathrm{g}$ ethidium bromide $\mathrm{ml}^{-1}$ solution and viewed over UV light.

Distribution analysis. PCR was used to amplify the 878 bp internal portion of the clpX gene between nt 369 and 1246 from all 101 Brachyspira species strains using primer pair CLPX.369.DF1 and CLPX.1246.DR1 (Table 1).

Sequencing reactions. The full $\operatorname{clp} X$ gene was sequenced from 12 strains of Brachyspira pilosicoli, three strains of Brachyspira innocens, two strains each of Brachyspira hyodysenteriae and of Brachyspira intermedia and one strain of Brachyspira aalborgi. Initially, an external primer set, CLPX. - 140.SF1 and CLPX. +63.SR3 (Table 1), amplifying $1863 \mathrm{bp}$ that included the coding region of $c l p X$, was applied to chromosomal DNA from 20 Brachyspira spp. strains in $50 \mu$ PCRs. The PCR products were purified using an UltraClean PCR Clean-up kit (Mo Bio Laboratories). The purified PCR products then were sequenced using the three sequencing primer sets (Table 1) using an ABI PRISM Dye Terminator Cycle Sequencing Ready Reaction Mix (PE Applied Biosystems) and an ABI 373A DNA sequencer (PE Applied Biosystems), according to the manufacturer's specifications.

Phylogenetic analysis. Sequence data were edited using SEQED version 1.0.3 (PE Applied Biosystems) and compared with the sequence of the clpX gene of porcine Brachyspira pilosicoli strain 95/ 1000 strain (GenBank accession no. AY466377). The nucleotide and translated protein sequences were aligned using CLUSTALX and CLUSTALW multiple alignment software to obtain a similarity matrix of the 20 different strains of Brachyspira spp. A neighbour-joining phylogenetic tree based on a distance matrix was drawn using the BIOEDIT Sequence Alignment Editor (North Carolina State University) and MEGA 3.1 (Kumar et al., 2004).

In silico analysis. The $c l p X$ gene was analysed using BLASTP (Altschul et al., 1997), reverse-position-specific BLAST (RPS-BLAST; Marchler-Bauer

Table 1. PCR primers used to amplify all or part of the $c / p X$ gene in Brachyspira spp. strains

\begin{tabular}{|c|c|c|c|}
\hline Primer set & Primer name & Sequence $\left(5^{\prime} \rightarrow 3^{\prime}\right)$ & Product size $(b p)$ \\
\hline \multirow{2}{*}{$\begin{array}{l}\text { Distribution } \\
\text { analysis primers }\end{array}$} & CLPX.369.DF1 & ATGAGCAAAAAAAATAATAAGG & \multirow[t]{2}{*}{878} \\
\hline & CLPX.1246.DR1 & TCAAGCCATATAAGTTTTATC & \\
\hline $\begin{array}{l}\text { Sequencing } \\
\text { primers (set 1) }\end{array}$ & CLPX.697SR1 & GACCAATACTTGAATAAGGCTC & 1863 \\
\hline \multirow{2}{*}{$\begin{array}{l}\text { Sequencing } \\
\text { primers (set 2) }\end{array}$} & CLPX.579SF2 & GTCTTCCATTTGCACGTGCAG & \multirow[t]{2}{*}{-} \\
\hline & CLPX.1286SR2 & GCTCCCATATTCATAGTAGAAG & \\
\hline $\begin{array}{l}\text { Sequencing } \\
\text { primers (set 3) }\end{array}$ & CLPX. $+63 . S R 3$ & CATTATTTGCCAACTCCATTACTG & - \\
\hline \multirow[t]{2}{*}{ Cloning primers } & CLPX.4.CF1 & AGGGGATCCAGCAAAAAAAATAATAAGGAA & \multirow[t]{2}{*}{1782} \\
\hline & CLPX.1785.CR1 & TAAGAATTCTCAAGCCATATAAGTTTTATC & \\
\hline
\end{tabular}


et al., 2002) and CDART (Marchler-Bauer et al., 2005) to find protein domain similarities and functional architecture. SIGNALP (EMBOSS) (Bendtsen et al., 2004), PSORTB (Gardy et al., 2005), TMPRED (Hofmann \& Stoffel, 1993), PENCE (http://www.cs.ualberta. $\mathrm{ca} / \sim$ bioinfo/PA/Subcellular) and CELLO (http:/cello.life.nctu.edu.tw) were used to predict subcellular localization. The EMBOSS programs IEP and GEECEE also were used to identify the isoelectric point and the molecular mass of the $\mathrm{ClpX}$ protein and to calculate the GC content of the $c l p X$ gene.

Preparation of recombinant histidine-tagged ClpX. The entire $c l p X$ gene encoding 595 aa was amplified from the genomic DNA of Brachyspira pilosicoli strain WesB using primers CLPX.4.CF1 and CLPX.1785.CR1 (Table 1) using the optimized conditions described above. The amplified product was restricted with EcoRI and BamHI (New England Biolabs) in a double digest according to the manufacturer's instructions. The restricted insert DNA was purified using an UltraClean PCR Clean-up kit and cloned into an Xpress Protein Expression System (Invitrogen) according to the manufacturer's instructions. Recombinant histidine ( His $\left._{6}\right)$-tagged $\mathrm{ClpX}$ protein was expressed in E. coli BL21 Star (DE3)pLys (Invitrogen) in $2 \times$ YT medium supplemented with $100 \mu \mathrm{g}$ ampicillin $\mathrm{ml}^{-1}, 1 \mathrm{mM}$ IPTG and $1 \%(\mathrm{w} / \mathrm{v})$ glucose. Affinity chromatography using a NiNTA column (Qiagen) was applied to purify the recombinant $\mathrm{His}_{6}$ ClpX protein under denaturing conditions according to the manufacturer's instructions. The purified protein was dialysed against distilled water to remove denaturing agent and salts. The dialysed protein was then lyophilized and resuspended in PBS. Quantification of recombinant $\mathrm{His}_{6}-\mathrm{ClpX}$ protein was carried out by electrophoresis of serial dilutions of the protein and BSA and lysozyme standards $(100,250,500$ and $1000 \mathrm{ng})$ on an SDS-polyacrylamide gel and capturing the gel image using a densitometer (proxPRESS Proteomic Imaging System; PerkinElmer Life Sciences). The image was analysed using the PROTEOME 1D ANALYSER version 1.10 (PerkinElmer Life Sciences) to calculate protein concentration.

Preparation of mouse polyclonal antiserum against Brachyspira pilosicoli strain WesB. A whole-cell bacterin was prepared from Brachyspira pilosicoli strain WesB as described previously (Hampson et al., 2000). A total of $10^{8}$ formalin-treated WesB cells were emulsified in an equal volume of Freund's incomplete adjuvant (Sigma) in a total volume of $100 \mu \mathrm{l}$ and administered subcutaneously into five 5-week-old male $\mathrm{C} 3 \mathrm{H} / \mathrm{HeJ}$ mice (Western Australian State Animal Resource Centre) three times at 2-week intervals. Three weeks after the last inoculation, the mice were euthanized by methoxyflurane inhalation, followed by cervical dislocation. Blood was collected by cardiac puncture and the serum was separated and stored at $-20{ }^{\circ} \mathrm{C}$ until used in Western blot analysis.

Immunization of mice using recombinant $\mathbf{H i s}_{\mathbf{6}}-\mathrm{ClpX}$ protein. Ten $\mathrm{C} 3 \mathrm{H} / \mathrm{HeJ}$ male mice of 5 weeks of age were obtained from the Western Australian State Animal Resource Centre and housed in two groups each comprising five mice. The five mice in the vaccinated group were injected subcutaneously twice with a 2-week interval with $100 \mu \mathrm{g} \mathrm{His}_{6}-\mathrm{ClpX}$ protein emulsified in an equal volume of Freund's incomplete adjuvant in a total volume of $100 \mu$ l. The second group of five mice was left unvaccinated. Three weeks after the last inoculation, all of the mice were euthanized and the blood was collected as described above. Aliquots of $5 \mu$ lof the sera from the vaccinated mice were adsorbed by mixing with $5 \mu \mathrm{l}$ recombinant $\mathrm{His}_{6}-\mathrm{ClpX}$ protein at $300 \mathrm{ng}^{-1} \mathrm{l}^{-1}$ in $\mathrm{PBS}$ and incubating at $37^{\circ} \mathrm{C}$ on a rotary mixer for $1 \mathrm{~h}$.

Western blot analysis using sera from immunized mice. The mouse sera were analysed by Western blot analysis against both whole-cell protein preparations of Brachyspira pilosicoli and the recombinant $\mathrm{His}_{6}-\mathrm{ClpX}$ protein. For preparation of whole-cell proteins, cells of Brachyspira pilosicoli strain WesB were suspended in PBS at a concentration of $10^{8}$ cells $\mathrm{ml}^{-1}$ and sonicated on ice for three cycles of $30 \mathrm{~s}$ with a $2 \mathrm{~min}$ rest between each cycle. The sonicate was centrifuged at $10000 \mathrm{~g}$ for $10 \mathrm{~min}$ and the supernatant was separated for a blot assay (Hampson et al., 2000). The total protein concentration was quantified using a Bio-Rad protein assay kit, according to the manufacturer's instructions. Ten micrograms of cell protein was separated by $12.5 \%(\mathrm{w} / \mathrm{v})$ denaturating SDS-PAGE in a Tris/glycine buffer system. The loaded protein was then transferred electrophoretically to a $0.2 \mu \mathrm{m}$ nitrocellulose membrane. The membrane was blocked with TBS-T (Tris-buffered saline supplemented with $0.05 \%, \mathrm{v} / \mathrm{v}$, Tween 20$)$ containing $5 \%(\mathrm{w} / \mathrm{v})$ skimmed milk powder for $1 \mathrm{~h}$, followed by three washings with TBS-T. The membrane was assembled into a multi-screen apparatus (Bio-Rad) for multiple serum analysis. Mouse sera were diluted 100-fold in $100 \mu \mathrm{l}$ TBS-T or 50-fold for the adsorbed sera, added to the membrane through the wells of the multi-screen probe and incubated for $1 \mathrm{~h}$ at room temperature with gentle mixing. The membrane was reacted with a $1: 2500$ dilution of goat anti-mouse IgG-alkaline phosphatase conjugate (Sigma) for $1 \mathrm{~h}$ at room temperature, followed by three washes with TBS. Immunodetection of proteins was carried out using $10 \mathrm{ml}$ developing buffer $[100 \mathrm{mM}$ Tris/ $\mathrm{HCl}(\mathrm{pH}$ 9.5), $100 \mathrm{mM} \mathrm{NaCl}, 5 \mathrm{mM} \mathrm{MgCl}$ ] containing $0.33 \mathrm{mg}$ nitro blue tetrazolium chloride (Sigma) $\mathrm{ml}^{-1}$ and $0.165 \mathrm{mg}$ 5-bromo-4chloro-3-indolyl phosphate (Sigma) $\mathrm{ml}^{-1}$. For Western blotting using recombinant $\mathrm{His}_{6}-\mathrm{ClpX}$ protein, $10 \mu \mathrm{g}$ of the recombinant protein was used. All other procedures were the same as described above.

Western blot immunoreactivity of $\mathrm{His}_{6}-\mathrm{ClpX}$ protein with human sera. Human sera were also reacted in Western blots with recombinant $\mathrm{His}_{6}-\mathrm{ClpX}$ protein as described for mouse sera, except that anti-human IgG-alkaline phosphate conjugate was used.

The 33 human sera tested were obtained as part of a previous study (Brook et al., 2001); they comprised 12 samples from migrant individuals from developing countries who, at the time of sampling, were colonized by Brachyspira pilosicoli as determined by faecal culture and PCR, five samples from migrant individuals who were negative for Brachyspira pilosicoli and 16 samples from healthy, culture-negative individuals from Perth, Western Australia.

\section{RESULTS AND DISCUSSION}

\section{Distribution of the clpX gene in Brachyspira spp.}

The 878 bp internal portion of the 1785 bp clpX gene was amplified by PCR from 29 of 35 strains $(83 \%)$ of Brachyspira pilosicoli, six of 24 strains (25\%) of Brachyspira hyodysenteriae, 14 of 16 strains (88\%) of Brachyspira intermedia, six of 17 strains (35\%) of Brachyspira innocens, one of six strains (17\%) of Brachyspira murdochii, one of two (50\%) strains of Brachyspira aalborgi and not from the single strain of Brachyspira alvinipulli. Given the known important functional roles of $\mathrm{ClpX}$ in other bacterial species, it is likely that a form of the $\operatorname{clp} X$ gene was present in all of the strains tested, but that heterogeneity at the primer sites used prevented PCR amplification. In any case, it was established that the gene was common in strains and species from throughout the genus and that this broad distribution represents an important advantage if ClpX were to be used as a component of a subunit vaccine. 


\section{Comparative analysis of the $c / p X$ gene and protein}

The $c l p X$ gene in the 20 strains in which it was sequenced was highly conserved, sharing $99.3-99.7 \%$ similarity at the nucleotide level and 99.7-100\% at the amino acid level. The nucleotide sequence for clpX in Brachyspira pilosicoli strain 95/1000 was identical to those in Brachyspira intermedia strains OR2 and OF11, whilst the peptide sequences of $c l p X$ in nine strains including Brachyspira pilosicoli strains 'S. jonesii', WesB and Q98.0026, Brachyspira innocens strains B256 ${ }^{\mathrm{T}}$, Q91-12233 and Q911530-1, Brachyspira intermedia strains OR2 and OF11 and Brachyspira hyodysenteriae strain 155.11 were identical to those in Brachyspira pilosicoli strain 95/1000. The other strains had one or two amino acid differences (Table 2) and these occurred throughout the molecule. Five strains had a substitution of asparagine for serine at position 154 . The general conservation of the protein across the different strains and species again is advantageous for subunit vaccine development.

The dendrogram constructed based on the $c l p X$ sequences is shown in Fig. 1. The sequences started at the ATG start codon and ended at the stop codon. The genes from six of the 12 strains (50\%) of Brachyspira pilosicoli were located in cluster IV, whilst the genes from the others, including $95 / 1000$, were found in the other three clusters, together with those from other Brachyspira spp. The general imperfect match of the dendrogram with the accepted phylogeny of the Brachyspira spp. may have been associated with recent mutational changes in $\operatorname{clp} X$ or with horizontal gene transfer and genetic recombination between the species. There was no consistent clustering of Brachyspira pilosicoli strains according to the host species of origin, consistent with strains being able to cross species boundaries and potentially being zoonotic (Hampson et al., 2006b).

\section{In silico analysis of the clpX gene and protein}

A BLASTP similarity search on ClpX found $38-44 \%$ peptide identity between the Brachyspira pilosicoli strain 95/1000 $\mathrm{ClpX}$ and the ATP-dependent ClpX of a variety of bacteria including Thermotoga maritima, Thermotoga naphthophila, Rickettsia conorii, Rickettsia prowazekii, Rickettsia rickettsii, Streptococcus thermophilus, Borrelia burgdorferi, Borrelia garinii, Legionella pneumophila, Treponema denticola, Clostridium perfringens, Staphylococcus aureus, Staphylococcus epidermidis, Bacillus cereus, Leptospira interrogans, Salmonella enterica and Francisella tularensis. As described by Trott et al. (2003), the Brachyspira ClpX had an extra $\sim 200$ amino acids at the N-terminal end of the protein compared with the ClpX protein in these other species and, consequently, the similarities were all in the C-terminal end of the molecule. The only similarity found at the $\mathrm{N}$ terminal end was to the ATP-dependent zinc metallopeptidase of Bacillus halodurans, which had about $8 \%$ amino acid similarity with the $\mathrm{N}$-terminal protein sequence from the ClpX of Brachyspira pilosicoli strain 95/1000.

RPS-BLAST analysis identified a 409 aa domain (residues 175-583) that was similar to the ATP-dependent Clp protease ATP-binding subunit clpX of Bacillus halodurans (GenBank accession no. Q9K8F4). The conserved domain architecture retrieval tool (CDART) identified a 105 aa region (residues 274-378) of the ClpX polypeptide that showed functional and architectural similarity to the Ruvb domain of the Thermus thermophilus Hb8 protein (GenBank accession no. 1HQCA).

Results from SIGNALP showed that the Brachyspira ClpX had no signal peptide in the 70 aa of its $\mathrm{N}$-terminal sequence. PSORT predicted ClpX as a bacterial inner-membrane protein, whilst PSORT-B recognized it as a protein with unknown localization in the cell. PENCE and CELLO recognized ClpX as a cytoplasmic protein with high

Table 2. Amino acid substitutions in ClpX proteins of eight strains of Brachyspira pilosicoli and of Brachyspira aalborgi strain $513^{\top}$ and Brachyspira hyodysenteriae strain 884 compared with Brachyspira pilosicoli reference strain 95/1000 (GenBank accession no. AY466377)

\begin{tabular}{|llcll|}
\hline No. of strains & Strain ID & $\begin{array}{c}\text { Position of different } \\
\text { amino acid }\end{array}$ & $\begin{array}{c}\text { Amino acid in } \\
\text { sequenced strain }\end{array}$ & $\begin{array}{c}\text { Amino acid in } \\
\text { strain } \mathbf{9 5 / 1 0 0 0}\end{array}$ \\
\hline 2 & HRM2B & 154 & Asparagine & Serine \\
\hline 3 & V1H91 & 225 & Aspartic acid & Glutamic acid \\
& $513^{\mathrm{T}}$ & & & \\
M1 & P43/6/78 & 483 & Asparagine & Aspartic acid \\
1 & Margaret & 569 & Aspartic acid & Glutamic acid \\
1 & 884 & 154 & Asparagine & Serine \\
1 & HRM7 & 444 & Methionine & Isoleucine \\
& & 8 & Lysine & Glutamic acid \\
2 & D17 & 154 & Asparagine & Serine \\
\hline
\end{tabular}


Cluster

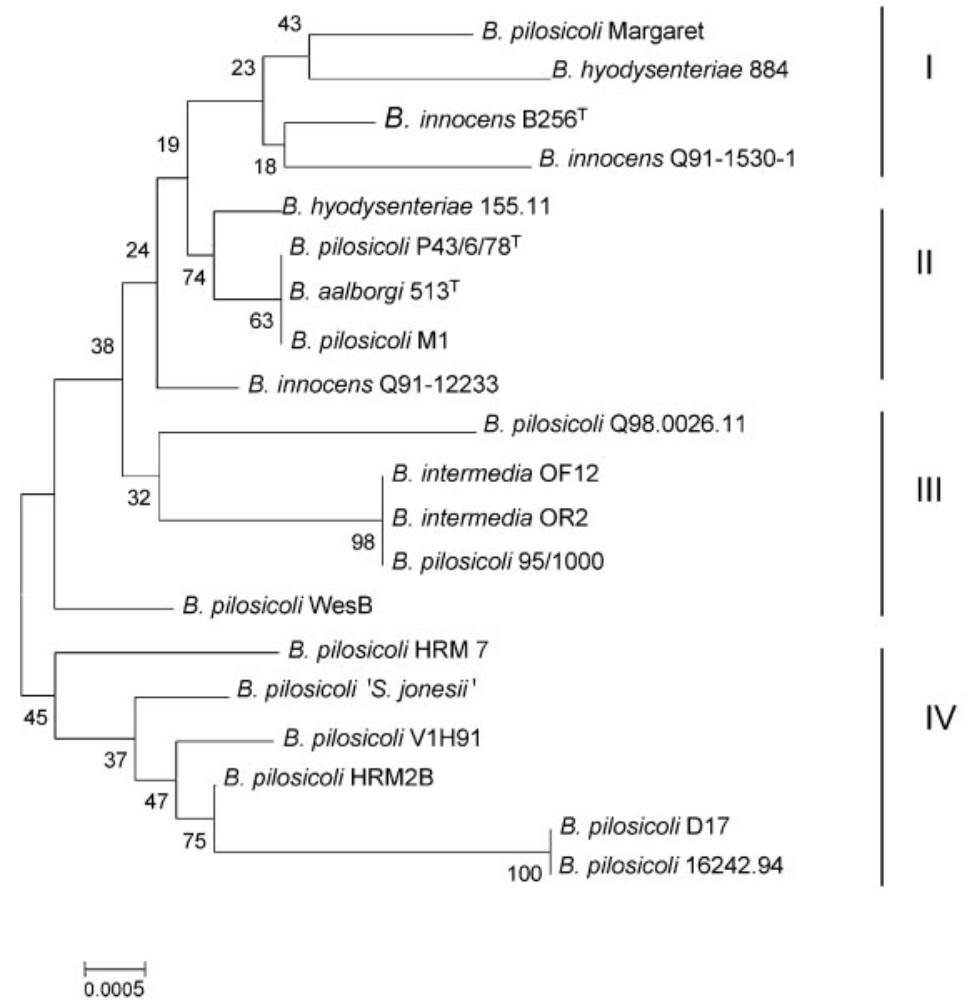

Fig. 1. Dendrogram constructed by the neighbour-joining method from the MEGA 3.1 software using the entire $1785 \mathrm{bp} c / p X$ gene. The tree comprised $c / p X$ genes from 20 strains of intestinal spirochaetes. The number adjacent to the nodes shows the bootstrap percentage. Bar, 0.0005 nucleotide substitutions per site. prediction scores. The TMPRED software predicted a possible 24-residue transmembrane helix at aa 396-419. Searches with IEP and GEECEE predicted a molecular mass for ClpX of 67.42 $\mathrm{kDa}$, a pI of 6.74 and a GC content of $28.06 \mathrm{~mol} \%$.

These in silico results generally agreed with those of Trott et al. (2003). As the Brachyspira ClpX protein had no signal peptide or obvious transmembrane region, it is likely to be cytoplasmic, but may be associated with the inner membrane. An inner-membrane and possible outer-membrane localization was suggested by Trott et al. (2003), based on partitioning of the molecule in different cell fractions. The general conservation of amino acid sequence at the $\mathrm{N}$ terminal end emphasizes the unique nature of the $\mathrm{ClpX}$ proteins in Brachyspira spp., but no clues were found as to the likely function of the unusual $\mathrm{N}$-terminus.

\section{Expression and immunogenicity of the $\mathrm{His}_{6}-\mathrm{ClpX}$ protein in mice}

The native ClpX protein had a predicted molecular mass of $67.42 \mathrm{kDa}$ according to its amino acid sequence and an (a)

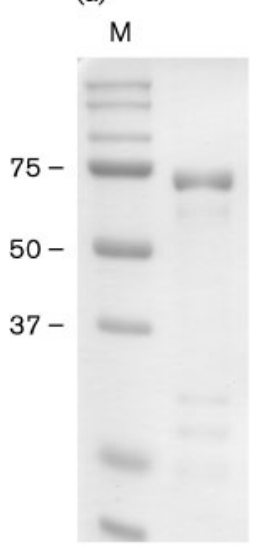

(b)

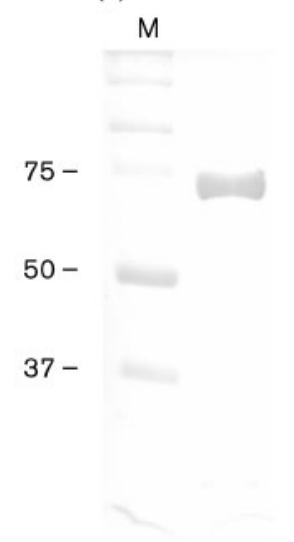

(c)

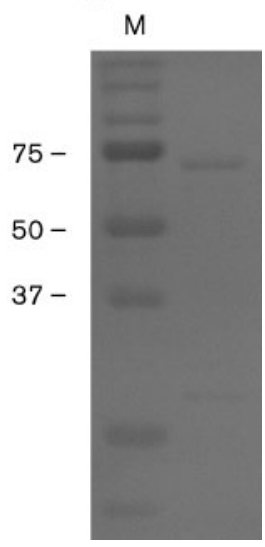

Fig. 2. Detection of $\mathrm{His}_{6}-\mathrm{ClpX}$ protein. (a) Coomassie brilliant blue-stained gel showing purified recombinant $\mathrm{His}_{6}-\mathrm{ClpX}$ protein. (b) Immunoblot detection of purified recombinant $\mathrm{His}_{6}-\mathrm{ClpX}$ protein using anti-His antibody and anti-mouse lgG-alkaline phosphatase conjugate. (c) Western blot reactivity of mouse serum raised against a bacterin preparation of Brachyspira pilosicoli strain WesB and reacted with purified recombinant $\mathrm{His}_{6}-\mathrm{ClpX}$ protein. $M$, Molecular mass markers ( $k D a)$. 
apparent molecular mass of $71.5 \mathrm{kDa}$ as a His-tagged protein (Fig. 2). In Western blot analysis, the recombinant $\mathrm{His}_{6}-\mathrm{ClpX}$ protein reacted strongly with mouse sera raised against whole-cell proteins of Brachyspira pilosicoli strain WesB (Fig. 2). Likewise, sera from the mice vaccinated with the recombinant $\mathrm{His}_{6}-\mathrm{ClpX}$ protein reacted strongly with a $\sim 67 \mathrm{kDa}$ band in the whole-cell preparations of Brachyspira pilosicoli strain WesB (Fig. 3). Sera absorbed with recombinant $\mathrm{His}_{6}-\mathrm{ClpX}$ protein no longer reacted with this band (data not shown). These results are encouraging for future development of Brachyspira ClpX as a vaccine subunit, as they demonstrate that native $\mathrm{ClpX}$ stimulates an immune reaction and that the recombinant His-tagged $\mathrm{ClpX}$ is immunogenic. Further work is required to evaluate whether vaccination with recombinant $\mathrm{ClpX}$ can provide protection against Brachyspira spp. infections.

\section{Reactivity of human sera with recombinant His $_{6}-$ ClpX protein}

All of the human sera, whether or not the individuals were colonized with Brachyspira pilosicoli, reacted with the ClpX recombinant protein in Western blots (data not shown). This broad serological reactivity probably represented crossreactivity, most likely resulting from previous exposure of these adults to other bacteria expressing forms of ClpX, although the possibility of prior exposure of all individuals to Brachyspira pilosicoli cannot be ruled out. These findings suggest that ClpX is unlikely to be a suitable serological reagent for use in detecting exposure to Brachyspira species, although it is possible that the unique $\mathrm{N}$-terminal end of the molecule could be more serologically conserved. Further work is required to investigate this possibility.

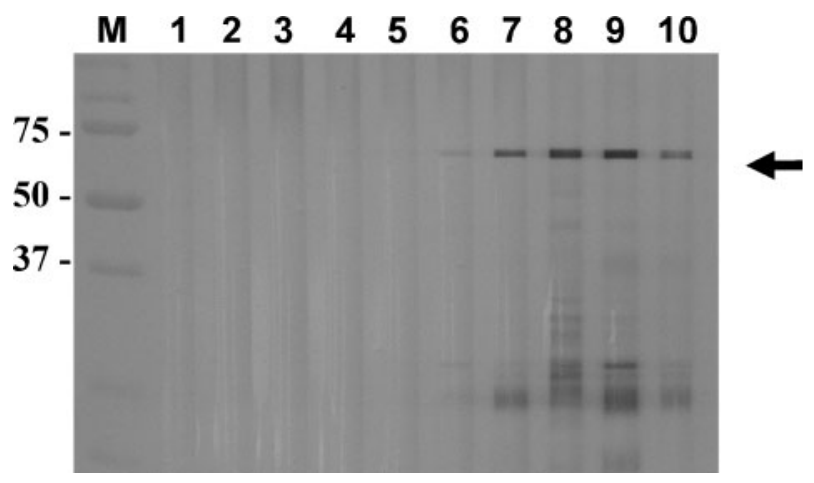

Fig. 3. Western blot reactivity of mouse sera raised against the recombinant $\mathrm{His}_{6}-\mathrm{ClpX}$ protein and reacted with whole-cell protein extracts of Brachyspira pilosicoli. Lanes 1-5, normal mouse sera (negative controls); lanes $6-10$, serum samples from individual immunized mice. $\mathrm{M}$, Molecular mass marker (kDa).

\section{ACKNOWLEDGEMENTS}

This study was supported by grants from Novartis Animal Vaccines, the Australian Research Council and the Razi Vaccine \& Serum Research Institute in Iran. We gratefully acknowledge David Dunn, Tom La and Nyree Phillips for their advice and excellent technical assistance.

\section{REFERENCES}

Altschul, S. F., Madden, T. L., Schäffer, A. A., Zhang, J., Zhang, Z., Miller, W. \& Lipman, D. J. (1997). Gapped BLAST and PSI-BLAST: a new generation of protein database search programs. Nucleic Acids Res 25, 3389-3402.

Bendtsen, J. D., Nielsen, H., Heijne, G. \& Brunak, S. (2004). Improved prediction of signal peptides: SignalP 3.0. J Mol Biol 340, 783-795.

Brook, C. J., Clair, A. N., Mikosza, A. S. J., Riley, T. V. \& Hampson, D. J. (2001). Carriage of intestinal spirochaetes by humans: epidemiological data from Western Australia. Epidemiol Infect 127, 369-374.

Gardy, J. L., Laird, M. R., Chen, F., Rey, S., Walsh, C. J., Ester, M. \& Brinkman, F. S. L. (2005). PSORTb v.2.0: expanded prediction of bacterial protein subcellular localization and insights gained from comparative proteome analysis. Bioinformatics 21, 617-623.

Gottesman, S., Clark, W. P., Lagard, V. C. \& Maurizi, M. R. (1993). $\mathrm{ClpX}$, an alternative subunit for the ATP-dependent Clp protease of Escherichia coli. J Biol Chem 268, 22618-22626.

Hampson, D. J. \& Duhamel, G. E. (2006). Porcine colonic spirochetosis/intestinal spirochetosis. In Diseases of Swine, 9th edn, pp. 755-767. Edited by B. E. Straw, J. J. Zimmerman, S. D'Allaire \& D. J. Taylor. Oxford: Blackwell Publishing.

Hampson, D. J. \& Stanton, T. B. (editors) (1997). Intestinal Spirochaetes in Domestic Animals and Humans. Wallingford, UK: CABI.

Hampson, D. J., Robertson, I. D., La, T., Oxberry, S. L. \& Pethick, D. W. (2000). Influences of diet and vaccination on colonisation of pigs by the intestinal spirochaete Brachyspira (Serpulina) pilosicoli. Vet Microbiol 73, 75-84.

Hampson, D. J., Fellström, C. \& Thomson, J. R. (2006a). Swine dysentery. In Diseases of Swine, 9th edn, pp. 785-805. Edited by B. E. Straw, J. J. Zimmerman, S. D’Allaire \& D. J. Taylor. Oxford: Blackwell Publishing.

Hampson, D. J., Oxberry, S. L. \& La, T. (2006b). Potential for zoonotic transmission of Brachyspira pilosicoli. Emerg Infect Dis 12, 869-870.

Harland, W. A. \& Lee, F. D. (1967). Intestinal spirochaetosis. Brit Med J 3, 718-719.

Hofmann, K. \& Stoffel, W. (1993). Tmbase - a database of membrane spanning proteins segments. Biol Chem Hoppe Seyler 347, 166.

Kumar, S., Tamura, K. \& Nei, M. (2004). MEGA3: integrated software for molecular evolutionary genetics analysis and sequence alignment. Brief Bioinform 5, 150-163.

Kunkle, R. A., Harris, D. L. \& Kinyon, J. M. (1986). Autoclaved liquid medium for propagation of Treponema hyodysenteriae. J Clin Microbiol 24, 669-671.

Marchler-Bauer, A., Panchenko, A. R., Shoemaker, B. A., Thiessen, P. A., Geer, L. Y. \& Bryant, S. H. (2002). CDD: a database of conserved domain alignments with links to domain three-dimensional structure. Nucleic Acids Res 30, 281-283.

Marchler-Bauer, A., Anderson, J. B., Cherukuri, P. F., DeWeeseScott, C., Geer, L. Y., Gwadz, M., He, S., Hurwitz, D. I., Jackson, J. D. \& 
other authors (2005). CDD: a Conserved Domain Database for protein classification. Nucleic Acids Res 33, D192-D196.

Mikosza, A. S. J. \& Hampson, D. J. (2001). Human intestinal spirochetosis: Brachyspira aalborgi and/or Brachyspira pilosicoli? Anim Health Res Rev 2, 101-110.

Skinner, M. M. \& Trempy, J. E. (2001). Expression of clpX, an ATPase subunit of the clp protease, is heat and cold shock inducible in Lactococcus lactis. J Dairy Sci 84, 1783-1785.
Trott, D. J., Alt, D. P., Zuerner, R. L., Wannemuehler, M. J. \& Stanton, T. B. (2001). The search for Brachyspira outer membrane proteins that interact with the host. Anim Health Res Rev 2, 19-30.

Trott, D. J., Alt, D. P., Bulach, D. M., Zuerner, R. L. \& Stanton, T. B. (2003). Identification of a membrane-bound clip protease (ClpX) homologue in Brachyspira pilosicoli. In Proceedings of the 2nd International Conference on Colonic Spirochaetal Infections in Animals and Humans, Eddlestone, Scotland. Abstract 59. 